\title{
ARE WE ALIVE WHEN ISLAMIC BANKS DOMINATE?: CASE STUDY IN INDONESIA
}

\author{
Raditya Sukmana (momyadit@gmail.com) \\ University of Airlangga \\ Heri Kuswanto \\ Sepuluh Nopember Institute of Technology Indonesia
}

\begin{abstract}
Islam promotes justice in every aspect of life including in banking and finance. Shariah has to be the foundation for any banking transactions to ensure that any single party is not being unfairly treated or exploited. Interest based bank is certainly create unfairness and exploitation. In any cases only single party which get a lot of benefit. Hence islamic banking industry need to be developed so that its market share will increase significantly until it can reach the domination of the national banking assets. This paper aims to forecast when such condition will occur. Adopting a popular forecasting tool such as double exponential smoothing, this study will inform us when islamic banking market share will reach $50 \%$ out of total banking asset. The monthly data examined starts from January 2004 to may 2011 . We use a single time series data which is islamic banking market shares whereby it is calculated from the islamic banking asset divided by total banking asset. the structure of this paper is as follows: after the introduction which describe the history and performance of Indonesian islamic bank, it discusses about the data and method used in this paper. Next section is on the description and analysis on the result obtained. Lastly is the conclusion where it recommends some policies required from the obtained result in which the optimist scenario would say that the domination of Islamic banks may occur in our grandchild generation
\end{abstract}

\section{INTRODUCTION}

Although the Muslim population in Indonesia reaches more than $70 \%$, the establishment of Islamic banks was relatively late as compared to the neighbouring country, Malaysia. The first Islamic bank namely Bank Muamalat Indonesia (BMI), which was established in November 1 1991, was highly supported by the then President of Indonesia, Suharto. Up to the current time, Indonesia, unlike Malaysia, does not have an Islamic Banking Act. The existing Islamic banks are under the revision of the conventional banking act which mentions that the banks have been allowed to operate other types of banking system which does not use interest. Besides Islamic banks, there exists also the Islamic Rural Banks and Islamic Banking Units.

Eight years after the establishment of the first Islamic bank, the second bank known as Bank Syariah Mandiri was established, the. It was a conversion of the conventional bank, Bank Susila Bakti. In the same year, Islamic Banking Unit were established. It is a unit within conventional banks which offer Islamic banking products. However, the difference between Malaysia and Indonesia is that Malaysia uses Islamic windows, whereby within the office of conventional banks, there exists a different counter for Islamic banking products. In Indonesia, conventional banks would normally have a separate building as well as separate management.

Bank Muamalat performed good in the early years of its commencement. In the second year of its existence, deposit increased from 20,800 million Rupiah in 1992 to 60,320 million in 1993. Similarly, financing also increased very significantly, from 32,650 million Rupiah to 92,000 million Rupiah in the subsequent year (Table 1). The following years, BMI was able to maintain good performance. However, the Asian crisis in 1997 created damage to the banking system. Not only did the conventional banks suffer, Islamic Banks were also affected. Table 1 shows that in 1998, Islamic banking assets, financing and deposit were declining very significantly. Growth of those three indicators shows contractions of $18.3 \%, 30.5 \%$, and $15.4 \%$ respectively. 
At that time, Bank Indonesia had to increase the interest rate in a significant rate to prevent further deterioration of the Rupiah due to capital flight. Consequently, this high interest rate caused the withdrawal of funds from the Islamic banks to conventional banks. This kind of situation known as the displacement commercial risk had to be faced by Islamic banks. It is the risk whereby depositors withdraw their money from Islamic banks and put it in the conventional banks due to more attractive interest rates given by their conventional counterparts. Nevertheless, in 1999, Islamic banks were able to recover. Asset, Financing and Deposit increased to $44.5 \%, 8.05 \%$ and $34.7 \%$ respectively.

The growth of Islamic banks in Indonesia, although increased significantly in the nominal term, did not increase in terms of the percentage share of the total banking asset. In 2000, total Islamic banking assets amounted to Rp 1,790,168 million and that amount accounted for only $0.17 \%$ of total banking assets. 2004 marked the year in which the proportion of Islamic banking assets out of total banking assets reached beyond 1\% (Shariah Banking Statistics, August 2004). Comparing the percentage share of the total banking assets between Malaysia and Indonesia, Malaysia is still far ahead of Indonesia. Currently, Islamic banking assets in Malaysia are over $10 \%$ out of total banking assets whereas in Indonesia it is around $2 \%$. This is of no surprise given the fact that Islamic banking in Malaysia was established ten years earlier than that of Indonesia.

Table 1. Performance of Islamic Banks in Indonesia

\begin{tabular}{|c|c|c|c|c|c|c|}
\hline Year & Asseta & Financing & Depositc & \multicolumn{3}{|c|}{ Growth (\%) } \\
\cline { 5 - 7 } & & & & Asset & Financing & Deposit \\
\hline 1992 & 120,880 & 32,560 & 20,800 & & & \\
\hline 1993 & 166,960 & 92,000 & 60,320 & 38.12 & 182.56 & 190.00 \\
\hline 1994 & 246,080 & 188,800 & 132,880 & 47.39 & 105.22 & 120.29 \\
\hline 1995 & 394,400 & 285,920 & 275,680 & 60.27 & 51.44 & 107.47 \\
\hline 1996 & 515,200 & 310,480 & 396,560 & 30.63 & 8.59 & 43.85 \\
\hline 1997 & 586,720 & 456,160 & 463,440 & 13.88 & 46.92 & 16.87 \\
\hline 1998 & 479,200 & 317,040 & 391,920 & -18.33 & -30.50 & -15.43 \\
\hline 1999 & 692,800 & 342,560 & 528,080 & 44.57 & 8.05 & 34.74 \\
\hline 2000 & $1,790,168$ & $1,271,162$ & $1,028,923$ & 158.40 & 271.08 & 94.84 \\
\hline 2001 & $2,718,770$ & $2,049,793$ & $1,806,366$ & 51.87 & 61.25 & 75.56 \\
\hline 2002 & $4,045,235$ & $3,276,650$ & $2,917,726$ & 48.79 & 59.85 & 61.52 \\
\hline 2003 & $7,858,918$ & $5,530,167$ & $5,724,909$ & 94.28 & 68.78 & 96.21 \\
\hline 2004 & $15,325,997$ & $11,489,933$ & $11,862,117$ & 95.01 & 107.77 & 107.20 \\
\hline 2005 & $20,879,874$ & $15,231,942$ & $15,582,329$ & 36.24 & 32.57 & 31.36 \\
\hline 2006 & $26,722,030$ & $20,444,907$ & $20,672,181$ & 27.98 & 34.22 & 32.66 \\
\hline 2007 & $36,537,637$ & $27,944,311$ & $28,011,670$ & 36.73 & 36.68 & 35.50 \\
\hline 2008 & $49,555,122$ & $38,194,974$ & $36,852,148$ & 35.6 & 36.68 & 31.55 \\
\hline 2009 & $66,090,000$ & $46,886,000$ & $52,271,000$ & 33.36 & 22.75 & 41.83 \\
\hline 2010 & $97,519,000$ & $68,181,000$ & $76,036,000$ & 47.55 & 45.41 & 45.46 \\
\hline
\end{tabular}

Note. $a, b, c$ are in Million IDR

Source: Bank Indonesia Shariah Banking Statistics, Various Issues and Harahap and Basri (2003)

With the brief performance of the Islamic banking industry above, it is then necessary to see how this industry will perform in the future. More specifically, stages of the development in the form of the blue print of Indonesian Islamic banks need to be designed in such away to bring the guidelines for the government as well as for the players to rightly move forward. This paper aims to add some more information on the stages by predicting the Islamic banking 
market shares in the futures. After the introduction, data and methods are followed. Next is to describe the empirical result obtained from the adopted methods. Limitations of the study will then be explained to bring some information of the weakness of this study. Lastly is the conclusion and some policy recommendation for the policy makers.

\section{DATA AND METHOD}

\section{Data}

All data are obtained from the bank Indonesia official website. In order to get Islamic bank market share, we obtained islamic banking asset as well as conventional banking asset. We then divide islamic banking asset over the summation of the total (Islamic and conventional banking asset). The monthly data is from January 2004 to May 2011. The limitation of this research is that. the islamic banking asset is only islamic full fledged and islamic window. The asset of islamic rural banks is excluded because the public disclosed data can much later. If we force to do so, we will have a fewer number of observation which may influence the forecasting ability. Moreover, with regard to the data on the conventional banking asset, the publicly disclosed data would not disaggregate the data of conventional banks and rural banks separately. As the data is a combination of the two, we would not be able to get the conventional banking asset only to be adopted in this study. Hence in this paper, the islamic banking asset (full fledge only) and conventional banking asset (including the rural banking assets) are utilized

Method

This study adopts the most common tool to be used for forecasting that involves trend namely Double Exponential Smoothing. There are many time series methods available for forecasting series with trend such as Holt Winter and decomposition. However, we do not apply these methods as the models are developed by considering the seasonal effect. In this case, we do not observe any seasonality in the series as shown in Figure 1. The figure clearly indicates that there is an increasing level with a trend.

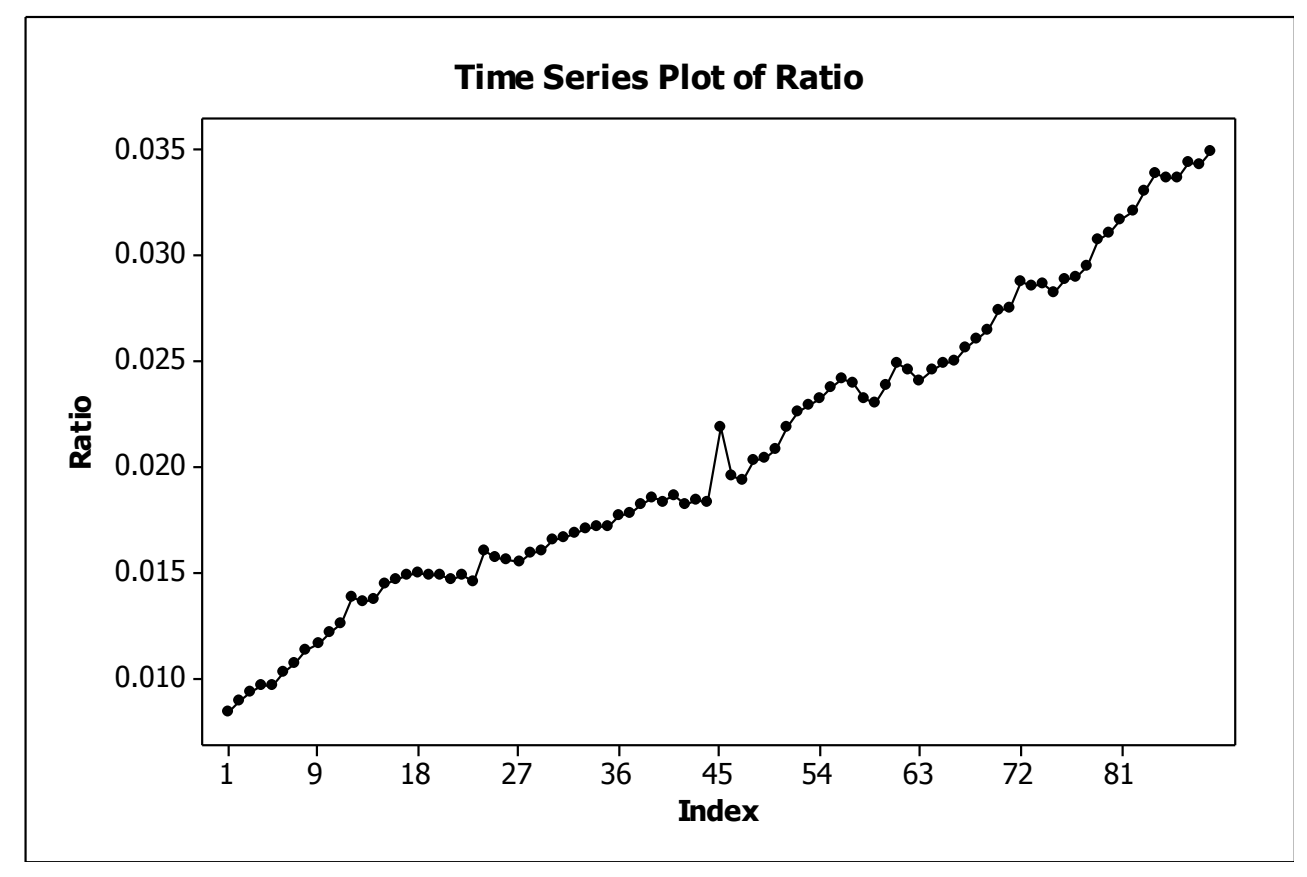

Figure 1. Time Series Plot of The Ratio 
The traditional method of ARIMA could not be used in this study as ARIMA can only be utilized on the stationary data (no trend) and it is a tool for short term forecast. As the objective of the study is for the long term, then the use of ARIMA may get bias result. Brief description about double exponential smoothing is described in the following part.

\section{Double Exponential Smoothing}

This method is designed to capture trend in the series. If the single exponential smoothing has only $\alpha$ as the smoothing constant, double exponential smoothing has two smoothing constants (let say $\alpha$ and $\gamma$ ) which represent smoothing for level and trend. The level is a smoothed estimate of the value of the observation at the end of each period, while the trend is a smoothed estimate of average growth at the end of each period. The model is given by

$$
\begin{gathered}
L_{t}=\alpha Y_{t-1}+(1-\alpha)\left(L_{t-1}+T_{t-1}\right) \\
T_{t}=\gamma\left(L_{t}-L_{t-1}\right)+(1-\gamma) T_{t-1} \\
\hat{Y}_{t}=L_{t}+T_{t}
\end{gathered}
$$

Where $L_{t}$ is the level at time $t$, $a$ is the weight for the level, $T_{t}$ is the trend at time $t, g$ is the weight for the trend, $Y_{t}$ is the data value at time $t$, and $\hat{Y}_{t}$ is the fitted value, or one-stepahead forecast, at time t.

In this case, the weights for trend and level can be determined using two ways i.e. using optimal ARIMA $(0,2,2)$ and specified weight.

\section{RESULT}

Graph 1 shows the time series plot on the islamic banking market share, that is the total asset islamic bank divided by the total national banking asset (islamic banking asset plus conventional banking asset). the horizontal line shows months. It means that "1" refer to the January 2004, "9" refer to September 2004 and so on.

Moreover, from the graph 1 above, it can be clearly seen that islamic banking asset from time to time (since January 2004) shows a significant increase. The increase in the trend suggests that there is a specific pattern during the period of study. From the data, it shows that the first observation (January 2004), the islamic banking market share is $0.8 \%$ while in the last observation (may 2011), it shows 3.4\%.

With the trend that is shown from the graph 1 above, it can be temporally suggested that islamic banking asset can dominate the national banking asset. This paper aims to provide us with the information on when will that event (domination of islamic banks) be occurred.

Below is the result of the forecasting using Double Exponential Smoothing either using weight as the result of optimum ARIMA or specified weight. The specified weight is determined by perfoming some combinations of weight for level and weight for trend. The constraint that we use is the sum of both weights are equal to one. The following table presents the combination of weights with its corresponding Mean Absolute Percentage Error (MAPE). 
Table 2. Weight Combinations with Its Corresponding MAPE

\begin{tabular}{|l|l|l|l|l|l|l|l|l|l|}
\hline & \multicolumn{7}{|c|}{ weight } \\
\hline Level & 0.1 & 0.2 & 0.3 & 0.4 & 0.5 & 0.6 & 0.7 & 0.8 & 0.9 \\
\hline Trend & 0.9 & 0.8 & 0.7 & 0.6 & 0.5 & 0.4 & 0.3 & 0.2 & 0.1 \\
\hline MAPE & 4.1666 & 2.7819 & 2.3274 & 2.1975 & 2.1154 & 2.0738 & 2.0659 & 2.0613 & 2.0487 \\
\hline
\end{tabular}

From the table, we can clearly see that the optimum combination of the weights is reached for 0.9 (level) and 0.1 (trend). Furthermore we will compare this optimum combination with the optimum weights obtained using ARIMA $(0,2,2)$. The plots of the forecasts for both models are depicted in figure 2 and figure 3 respectively.

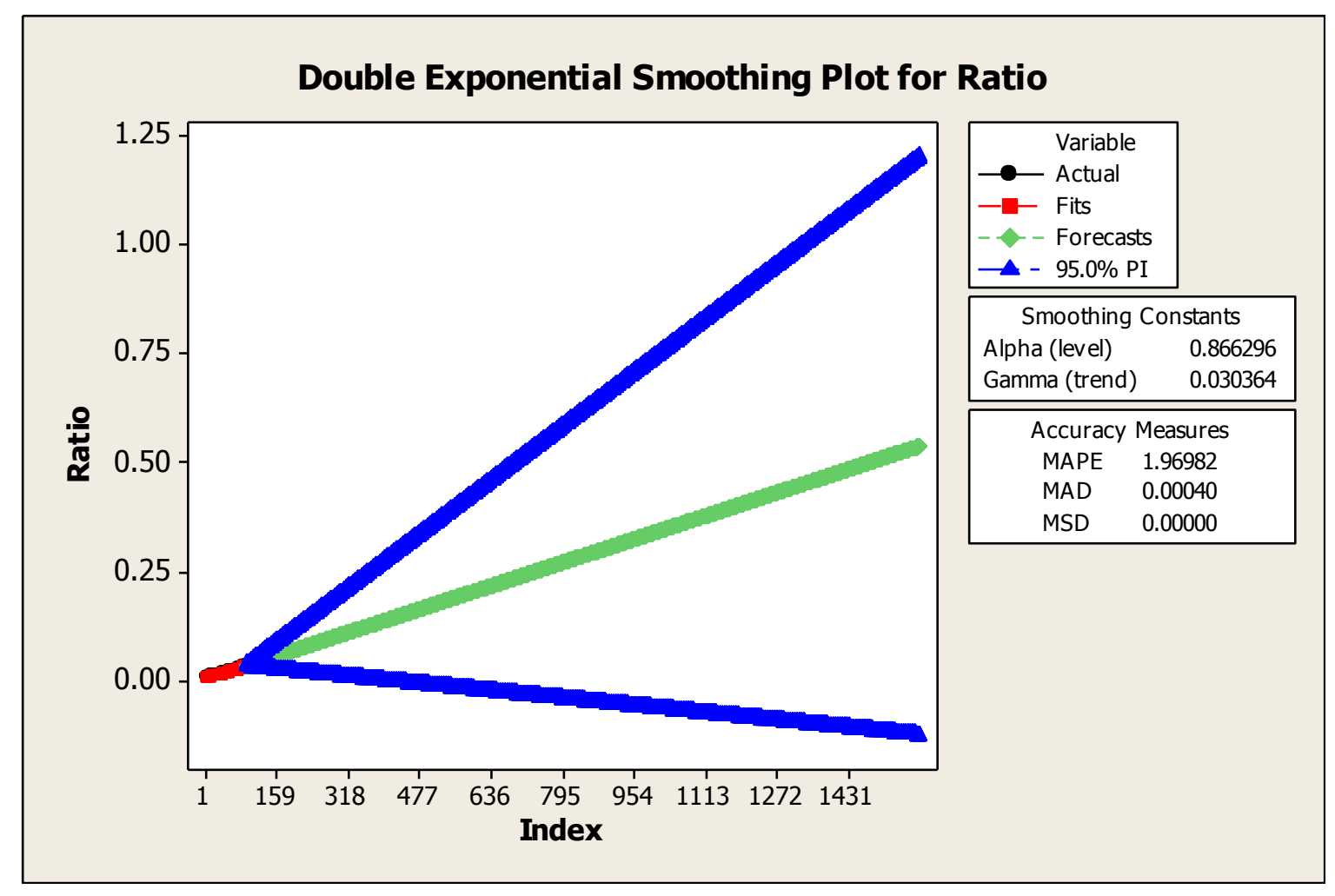

Figure 2. Forecast Plots Using Double Exponential Smoothing with Optimum ARIMA Weight 


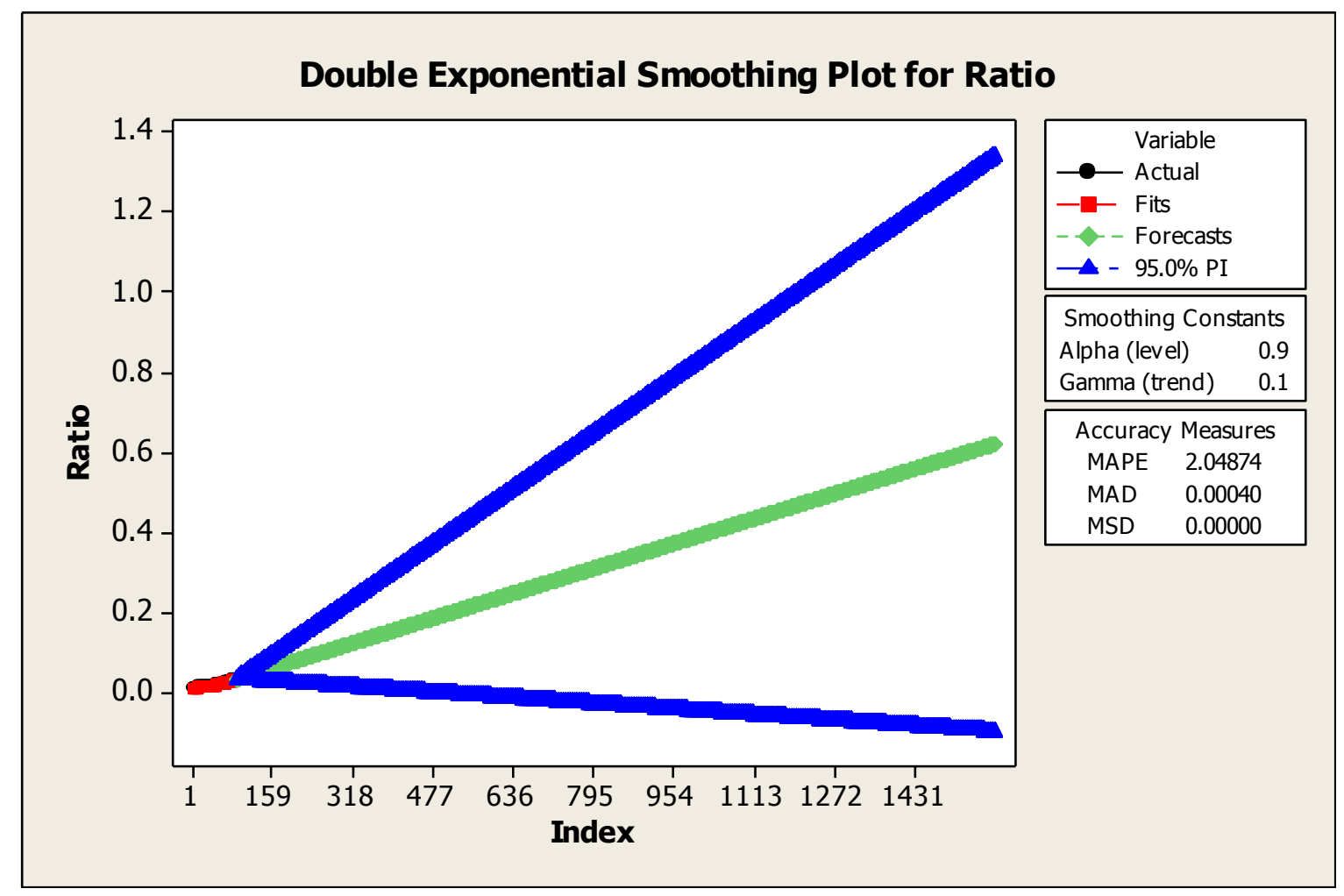

Figure 3. Forecast Plots Using Double Exponential Smoothing With Specified Weight

From both figures, the time series plot for the actual data is shown by red line and plot of forecasting is represented by green line. The blue line is the $95 \%$ confidence interval of forecasting for the intended period. in this context, forecasting starts from June 2011 to may 2136. With the double exponential smoothing approach using optimum ARIMA $(0,2,2)$, it shows that islamic banking market share will reach $50 \%$ in September 2126 . However, if we look at the upperline of the blue line (this line can be regarded as the optimist scenario), in March 2061 or next 50 years, islamic banking asset can be the champion. The optimist scenario here means that there are significant policies created to support islamic banking. However, the levels of these significant policies are still under the level of revolutionary policies.

From figure 3, we see that using own specified weights, the Islamic banking asset will reach $50 \%$ in July 2110 , while the optimistic condition estimate the period of reaching $50 \%$ in December 2055. This result seems strange as there is no consistency in the suggested period resulted from both approximation. In a normal condition, optimum ARIMA suggests shorter period, while in an optimistic condition the shorter period is suggested by own specified weights. This happen because the standard error of the forecast for the specified weights is getting higher and higher compared to the ARIMA $(0,2,2)$ weight. Indeed, the MAPE from model using optimum ARIMA $(0,2,2)$ weight is lower than the specified one.

Below is the summary which shows when will the domination of islamic bank occur using both approximations as well as providing pessimist and optimist scenario. 
Table 3. Result of the forecasting Islamic banking market share

\begin{tabular}{|c|c|c|}
\hline Model & $\begin{array}{c}\text { Optimum ARIMA } \\
(0,2,2)\end{array}$ & Optimum specified weight \\
\hline $10 \%$ & $\begin{array}{c}\text { Jul } 2027 \\
\text { (May 2018) }\end{array}$ & $\begin{array}{c}\text { Jun } 2025 \\
\text { (Aug 2017) }\end{array}$ \\
\hline $20 \%$ & $\begin{array}{l}\text { May } 2052 \\
\text { (Jan 2029) }\end{array}$ & $\begin{array}{l}\text { Aug } 2046 \\
\text { (Apr 2027) }\end{array}$ \\
\hline $30 \%$ & $\begin{array}{l}\text { Feb } 2077 \\
\text { (Oct 2039) }\end{array}$ & $\begin{array}{l}\text { Dec } 2067 \\
\text { (Oct 2036) }\end{array}$ \\
\hline $40 \%$ & $\begin{array}{l}\text { Dec } 2111 \\
\text { (Jul 2050) }\end{array}$ & $\begin{array}{l}\text { Apr } 2089 \\
\text { (May 2046) }\end{array}$ \\
\hline $50 \%$ & $\begin{array}{l}\text { Sept } 2126 \\
\text { (Mar 2061) }\end{array}$ & $\begin{array}{c}\text { Jul } 2110 \\
\text { (Dec 2055) }\end{array}$ \\
\hline
\end{tabular}

From Table 2 above, it results on the very optimistic of the growth and development of the Islamic banking industry in Indonesia. The result suggests that the market shares of Islamic banking industry will reach 10\% in 2018 (using the double exponential smoothing methods in an optimistic scenario). Another method has shown to be one year earlier where $10 \%$ market share to happen.

This result seems illogical or highly unlikely to be appeared in real fact. This is because until now in which Islamic banks has been in existence for almost 2 decades, its market share is still under $4 \%$. Whereas our prediction reveals that $10 \%$ will be reached in 7 years later. Hence it is unlikely that during these 7 years, the growth of the market share will be $10 \%$.

The forecasting tools that provide such result (in Table 1) have some limitation. These adopted forecasting methods assume that the existing system grows in a linear form, whereas in actual fact, it might not be the case. Secondly, the forecasted result is pretty much influenced by the setting of the parameter level and its trend in which we never know what will be the optimum value. This is because we there is no test to estimate the parameter.

In contrast with the optimistic scenario, the forecasted period for each market share seems to be realistic although in some cases it can be said as too short period. However, the market share is possible to be reached if the Islamic banking has a really good strategy in gathering the market.

\section{CONCLUSION AND POLICY RECOMMENDATION}

This paper aims to provide us with the information on when the islamic banking asset will dominate the national banking asset. Two approaches using double exponential smoothing have been adopted. All data adopted is from Bank Indonesia Website. The result shows that double exponential smoothing using optimum weight provide the fastest time to reach $50 \%$ that is in September 2126, while the other approximation provides the same time that is July 2110 . While to know when will happen is important, there are other things which equally important, that is how to achieve it.

As briefly explained earlier, optimist scenario can be obtained if there are various significant policy taken to support it. This policy will not be as that of revolutionary policy. Various significant policies here mean that there should be a strong government will to support it. Revolutionary policy in this case means that government suddenly create an unpopular 
policy such as close down all conventional banks and shifted all banking mechanism into islamic one. This policy is highly unlikely to be appeared in real fact. The speed up the evolution might be the better as opposed to the revolution. This speed up evolution would likely to be in line with the optimist scenarios.

Strong government will in supporting the islamic banks would mean that the policy should be designed in stages and in stage, a significant step has to be achieved. For example: government's policy may design that for the first five years all hajj payment have to be dealt with islamic banks only in the form of deposit such as being done by tabung haji. The next stage of five years, government's policy is to shift all regional government funds into islamic banks and so on.

This stage has to be taken by government in order to boost the performance of islamic banks. Why domination of islamic banking is important. It is because conventional bank with the use of riba based transaction are clearly exploitated and treats unfairness to parties involve. But the big question will be, when will that domination happen? Our result (with the stated limitation above) shows that it will happen in our grandchild generation, we may or may not be died by that time.

\section{REFERENCES}

Bank Indonesia. Statistik Perbankan Syariah (various edition).

G. E. Box, G.M.Jenkins, and G.C.Reinsel. 2003. Time Series Analysis. Pearson Education.

Lynwood A. Johnson Douglas C. Montgomery and John S. Gardiner. 1990. Forecasting and Time Series Analysis. McGraw-Hill,Inc, 2nd edition edition.

Wei, W. S. 2006. Time Series Analysis Univariate And Multivariate Methods. New-York: Philadelphia: Pearson.

Render, B., Stair Jr, R.M., and Hanna, M.E. 2006. Quantitative analysis for management, PrenticeHall. 